\title{
Importance of hypoglycemia on the risk of Alzheimer's disease in elderly subjects with diabetes mellitus
}

\author{
Sevilay Muratli' \\ Fatih Tufan ${ }^{2}$ \\ Ozlem Soyluk ${ }^{2}$ \\ Gulistan Bahat' \\ MAkif Karan' \\ 'Division of Geriatrics, Department \\ of Internal Medicine, ${ }^{2}$ Department \\ of Gerontology, Faculty of Medical \\ Sciences, Istanbul University, Istanbul, \\ Turkey
}

This article was published in the following Dove Press journal:

Clinical Interventions in Aging

3 November 2015

Number of times this article has been viewed

\section{Dear editor}

We read the article on the study of "Link between type 2 diabetes and Alzheimer's disease: from epidemiology to mechanism and treatment" by Li et al. ${ }^{1}$ The review is very detailed and rational, considering the link between diabetes and Alzheimer's disease and giving a new outlook as type 3 diabetes. It provides important information about the effects of the hyperglycemic complications of diabetes and treatment of dementia.

We would like to emphasize a very important aspect of the diabetes-dementia association. The negative effects of acute hypoglycemia on executive function in adults with diabetes are well known. ${ }^{2}$ Recent data indicate that hypoglycemic events may also precipitate dementia in the chronic period. ${ }^{3-5}$ In a 27 -year long longitudinal study involving 16,667 diabetic subjects with a mean age of 65 years, $11 \%$ developed dementia. ${ }^{3}$ Among subjects who developed dementia, $16.95 \%$ had at least one episode of hypoglycemia. Another prospective population-based study that involved 783 elderly adults suggested that subjects who experienced hypoglycemic events had a twofold increased risk of developing dementia compared with those who did not. ${ }^{4}$ Another study involving 169,114 cases with new-onset dementia indicated that subjects with diabetes had a higher risk of dementia if they had prior cerebrovascular disease, peripheral vascular disease, chronic kidney disease, or a history of one or more hospital admissions for hypoglycemia. ${ }^{5}$ Contribution of hypoglycemia to the development of dementia was also observed in a cohort study that consisted of 1,342 diabetic patients in Italy. ${ }^{6}$ In this study, multivariate analysis showed that advanced age, female sex, and hypoglycemic events were independently associated with increased risk of dementia. Moreover, the risk was higher in subjects under oral hypoglycemic drugs. There are also experimental studies regarding the effects of hypoglycemia on the risk of dementia. Hypoglycemia leads to hyperphosphorylation of tau in a study performed on rat brain cells. ${ }^{7}$

Patients with elderly-onset type 2 diabetes have better glycemic control and lower rates of microvascular complications than elderly subjects with adult-onset diabetes. ${ }^{8}$ Furthermore, hypoglycemic complications have the potential to be more dangerous because adrenergic symptoms of hypoglycemia are more silent in elderly diabetics. ${ }^{9}$ Thus, consideration of the adverse effects of hypoglycemia is crucial, especially in frail elderly subjects. Although it is important to control hyperglycemia in elderly subjects, avoidance from hypoglycemia is of paramount importance to lower the risk

Correspondence: Fatih Tufan Department of Gerontology, Faculty of Medical Sciences, Istanbul University, Demirkapi Avenue, Karabal Street, PB 34740, Bakirkoy, Istanbul, Turkey Tel +90212414 I500

$\mathrm{Fax}+902124141515$

Email fatihtufan@gmail.com 
of dementia. In this context, individualized glycemic targets should be utilized.

\section{Disclosure}

The authors report no conflicts of interest in this communication.

\section{References}

1. Li X, Song D, Leng SX. Link between type 2 diabetes and Alzheimer's disease: from epidemiology to mechanism and treatment. Clin Interv Aging. 2015;10:549-560.

2. Graveling AJ, Deary IJ, Frier BM. Acute hypoglycemia impairs executive cognitive function in adults with and without type 1 diabetes. Diabetes Care. 2013;36(10):3240-3246.

3. Whitmer RA, Karter AJ, Yaffe K, Quesenberry CP Jr, Selby JV. Hypoglycemic episodes and risk of dementia in older patients with type 2 diabetes mellitus. JAMA. 2009;301(15):1565-1572.
4. Yaffe K, Falvey CM, Hamilton N, et al. Association between hypoglycemia and dementia in a biracial cohort of older adults with diabetes mellitus. JAMA Intern Med. 2013;173(14):1300-1306.

5. Haroon NN, Austin PC, Shah BR, Wu J, Gill SS, Booth GL. Risk of dementia in seniors with newly diagnosed diabetes: a population-based study. Diabetes Care. 2015;38(10):1868-1875.

6. Pilotto A, Noale M, Maggi S, et al. Hypoglycemia is independently associated with multidimensional impairment in elderly diabetic patients. Biomed Res Int. 2014;2014:906103.

7. Lee CW, Shih YH, Wu SY, Yang T, Lin C, Kuo YM. Hypoglycemia induces tau hyperphosphorylation. Curr Alzheimer Res. 2013;10(3): 298-308.

8. Kirkman MS, Briscoe VJ, Clark N, et al. Diabetes in older adults. Diabetes Care. 2012;35(12):2650-2664.

9. Matyka K, Evans M, Lomas J, Cranston I, Macdonald I, Amiel SA. Altered hierarchy of protective responses against severe hypoglycemia in normal aging in healthy men. Diabetes Care. 1997;20(2):135-141. 


\section{Authors' reply \\ Li Xiao' \\ Dalin Song ${ }^{2}$}

'Affiliated Fuzhou First Hospital of Fujian Medical University, Fuzhou, ${ }^{2}$ Department of Geriatrics, Qingdao Municipal Hospital, Qingdao, People's Republic of China

Correspondence: Dalin Song

Department of Geriatrics, Qingdao Municipal Hospital, 5 Donghai

Middle Road, Qingdao 26607I, People's Republic of China

Tel +86 I856I72800I

Email billy_mei@I26.com

\section{Dear editor}

We have read the letter from Sevilay Muratli et al carefully. In the letter, they have fully elucidated that hypoglycemia is an important risk factor for Alzheimer's disease (AD) in the elderly subjects with diabetes mellitus. We totally agree with their statement. The reason why we did not incorporate this aspect in our article is that hypoglycemia is not the main symptom for type 2 diabetes mellitus, and additionally insulin resistance and deficiency emphasized within the review are not the links between $\mathrm{AD}$ and hypoglycemia. There are several possible explanations for the connection between hypoglycemia and cognitive decline: 1) during episodes of hypoglycemia, the increase in adrenaline levels leads to enhanced activity of platelet and leucocyte and promotes blood coagulation; ${ }^{1}$ 2) hypoglycemia induces focal neurological damage and transient ischemic attacks; ${ }^{2}$ and 3) another research showed that endothelial function was impaired during acute hypoglycemia. ${ }^{3}$ In a word, hypoglycemia should be considered in interpretations of cognitive decline in the elderly subjects with diabetes mellitus. And as they have stressed, glycemic targets should be individualized.

If we have more materials, we would like to write another review about hypoglycemia and $\mathrm{AD}$.

\section{Disclosure}

The authors report no conflicts of interest in this communication.

\section{References}

1. Fisher BM, Hepburn DA, Smith JG, Frier BM. Responses of peripheral blood cells to acute insulin-induced hypoglycaemia in humans: effect of alpha-adrenergic blockade. Horm Metab Res Suppl. 1992;26:109-110.

2. Fanelli CG, Porcellati F, Pampanelli S, Bolli GB. Insulin therapy and hypoglycaemia: the size of the problem. Diabetes Metab Res Rev. 2004;20(suppl 2):S32-S42.

3. Wright RJ, Newby DE, Stirling D, Ludlam CA, Macdonald IA, Frier BM. Effects of acute insulin-induced hypoglycemia on indices of inflammation: putative mechanism for aggravating vascular disease in diabetes. Diabetes Care. 2010;33(7):1591-1597.

Dove Medical Press encourages responsible, free and frank academic debate. The content of the Clinical Interventions in Aging 'letters to the editor' section does not necessarily represent the views of Dove Medical Press, its officers, agents, employees, related entities or the Clinical Interventions in Aging editors. While all reasonable steps have been taken to confirm the content of each letter, Dove Medical Press accepts no liability in respect of the content of any letter, nor is it responsible for the content and accuracy of any letter to the editor.

\section{Publish your work in this journal}

Clinical Interventions in Aging is an international, peer-reviewed journal focusing on evidence-based reports on the value or lack thereof of treatments intended to prevent or delay the onset of maladaptive correlates of aging in human beings. This journal is indexed on PubMed Central, MedLine,
CAS, Scopus and the Elsevier Bibliographic databases. The manuscript management system is completely online and includes a very quick and fair peer-review system, which is all easy to use. Visit http://www.dovepress. com/testimonials.php to read real quotes from published authors. 